\title{
3 Cash transfers as citizens' dividend of the resource boom
}

\author{
Opportunities and challenges of social \\ protection in Bolivia
}

\author{
Pablo Evia Salas
}

\section{Introduction}

Hydrocarbons play a crucial role in the Bolivian economy. According to data from the National Institute of Statistics (Instituto Nacional de Estadística, 2020), sectoral GDP had cumulative growth of $70 \%$ in the 2000 s, compared to average growth in the 1990s (around 4\%). Likewise, its role in Bolivian exports is significant: 40\% of export earnings in the timespan 2000-2018 came from this sector (Banco Central de Bolivia, 2019). In addition to being important from an economic point of view, hydrocarbons play a strategic role in Bolivian politics. No other sector from the industry has been subject to such varied institutional reform in a (relatively) short time horizon, influenced by the growing importance of the sector in its potential to increase the government revenues, mainly through tax collection.

This chapter explores the interaction between social policy innovations, understood as a type of institutional change, and the resource boom in Bolivia during 2003-2014 and raises a couple of questions regarding their sustainability. A series of reforms related to natural resources were introduced in Bolivia in the 1990s. These reforms paved the way for gathering more revenues from the natural resource sector (mainly natural gas), which allowed the successive governments to try to build a social protection system reflecting these increased fiscal revenues. They could, thus, be understood as a citizens' dividend of the resource boom (Arezki et al., 2012, p. 30).

The importance of these social protection innovations in overcoming the high poverty and inequality rates present in the country is generally accepted (Amarante \& Brun, 2018; Robles et al., 2019). However, in some periods, the social protection policy lacked the necessary financial support to be financially sustainable, which introduced social, fiscal, and political pressures that ended up twisting the objective under which they originally were conceived. In this sense, the social protection system in Bolivia faces some constraints and challenges that could compromise its financial sustainability and potentially put in danger the funding of the system and the support provided to its beneficiaries.

The institutional drivers of social policy innovations in Bolivia are mixed: First, there has been a strong regional influence in terms of social protection policies based on rigorous evaluations (Bolsa Família in Brazil, Oportunidades 
in Mexico). In fact, this type of policy influenced not only Bolivia but other countries in the region that adopted social protection schemes based on cash transfers (both conditional and unconditional).

On the other hand, innovations in social policy were also endogenously driven by the resource boom due to their discovery and subsequent boom in commodity prices. The flow of additional resources had to find a use by the government (apart from minimum wage increases, increased infrastructure investments, etc.), and therefore the establishment of conditional and unconditional transfers was propitious, as well as a way to create a political support base for the government of the party Movimiento al Socialismo (MAS, Movement towards Socialism), headed since 2006 by President Evo Morales (until 2019).

The remainder of the chapter consists of the following: Next, I discuss the background of the conception and implementation of the central social transfers after the economic reforms (1990s) and the natural resource's boom (2000s). Following that, I analyze the fiscal sustainability of the Bolivian social policy alongside its funding rationale, stressing some of its weaknesses and potential risks. In the last section, I will get into the challenges and the future of social protection in Bolivia, trying to conceive it as a life cycle-oriented policy.

\section{Background of social policy in Bolivia: domestic reforms and global boom}

The foundations of contemporary social policy in Bolivia could be traced back to the 1980s, in which a profound crisis unleashed an unprecedented erosion in the living conditions of most Bolivians, and predominantly the poorest and vulnerable. The collapse of international tin prices triggered a massive adjustment of the role of the government in the economy (which was the main employer of the country). This adjustment implied a massive layoff of workers, with the additional harmful consequences of the loss of purchasing power due to an episode of extremely high inflation (Antelo, 2000). At that time, the creation of the Fondo Social de Emergencia-Social Emergency Fund as an entity that supported the most vulnerable through the implementation of economic infrastructure, social assistance, and productive counseling installed the basis of social policy in the country based on direct government support (Romero, 1988).

Despite these efforts, poverty rates remained in the range of 50-70\% in the aftermath of the 1980s hyper-inflation episode. Since then, successive governments have tried to introduce market reforms in the country to try to correct the macroeconomic disequilibrium and recover the path for economic growth. In 1993, President Gonzalo Sánchez de Lozada started to implement another package of reforms aiming at modernizing state administration. These reforms included a substantial component in the hydrocarbons sector. Due to the sector's lack of investments, production had stagnated without further exploration activities undertaken by Yacimientos Petroliferos Fiscales Bolivianos (YPFB), a stateowned firm. In this sense, an essential part of the reforms during the 1990s included the attempt to invigorate the hydrocarbons sector through market reforms, including its partial privatization, to attract foreign investment. 
These reforms effectively appealed to a number of multinational firms working in the sector (AMOCO, Pérez Companc, ENRON, among others), which became involved in the business through the purchase of stock in the previously state-owned company, YPFB. The investment commitments of foreign capital enhanced the position of Bolivia in the hydrocarbon business at the regional level, including the construction of a natural gas pipeline to Brazil, which was a huge market for Bolivian hydrocarbons.

This privatization scheme included a social policy component: the BONOSOL (Bono Solidario-Solidarity Bond). BONOSOL consisted of a cash transfer paid annually to all Bolivian citizens proven to be 65 years old or older, using the profits of the partially privatized hydrocarbons companies. The BONOSOL's amount was initially about USD257 per year at the present exchange rate (USD1 = Bs7). As the byproduct of the hydrocarbons' reform, BONOSOL constituted the first cash transfer that is still part of the current social policy infrastructure. The following government of Banzer-Quiroga (1997-2002) renamed it as Bolivida and, given the economic crisis of the early 2000s, reduced the amount of the pension to only USD65 yearly.

The reforms in the hydrocarbon sector implemented by the first government of Sánchez de Lozada started to show results soon: new reserves of natural gas were discovered, and production increased in a spectacular way. Talks began to facilitate the exports of part of these additional reserves to foreign markets, the most important one being the Mexican and American markets.

In parallel to this incipient boom, Bolivia experienced during the years 2000 and 2005 a series of dramatic episodes of social upheaval and mobilizations including a social revolt against the privatization of water provision in the city of Cochabamba (the Water War), several weeks-long blockades of the Bolivian altiplano headed by the Aymara leader Felipe Quispe, and a revolt against a new direct income tax in February 2003 (Black February) led by the police forces. During "Black October" in 2003, also known as the War over Gas, weekslong massive protests took place against the plans of the second government of Gonzálo Sánchez de Lozada (2002-2003) for exporting Bolivian natural gas via a Chilean port. Many Bolivians objected to the selection of Chile because of the historical memory of Chile usurping Bolivia's access to the Pacific Ocean.

Black October terminated the presidential mandate of Gonzalo Sánchez de Lozada, forcing him to go into exile in the United States. Sánchez de Lozada's resignation resulted in the automatic succession of Vice President Carlos Mesa, who drafted a new law governing the hydrocarbons sector based on the results of a previously conducted popular referendum. This new law increased the taxes raised by the government to $50 \%$ of hydrocarbons' production, from the $18 \%$ established by Sánchez de Lozada. In this way, tax revenues from hydrocarbon production were dramatically increased. In 2005 the government received a total of USD607 million, which meant an increase of $112 \%$ compared to 2004 (USD286 million). At the same time, it motivated an intense conflict over the distribution of these windfalls among regions, local governments, and other stakeholders (such as public universities).

After this new round of intensive social protests, in December 2005 the leader of the coca grower union Evo Morales won the Bolivian presidency with 
approximately $52 \%$ of the votes, which meant the most resounding victory for a candidate for the presidency since the restoration of democracy in 1982. Morales won on the basis of an electoral campaign that promised the nationalization of the countries' natural resource sector. In May 2006, President Morales' government then issued the Supreme Decree Héroes del Chaco, ${ }^{1}$ declaring state ownership of all hydrocarbons. According to the decree, all oil- and gas-producing companies were obliged to hand over their hydrocarbon production to the public company YPFB. At the same time, YPFB assumed the commercialization of and definition of the conditions of sale, volumes, and prices of all hydrocarbons.

A transition period was established during which the existing contracts with foreign oil companies were readjusted and reformulated. Also, those oil fields whose production was greater than 100 million cubic feet per day were subject to an additional $32 \%$ tax on their production value. This percentage was added to the 50\% tax established in the new Hydrocarbons Law issued in 2005, making a total of $82 \%$ in taxes belonging to the state.

As a consequence of this reform, the state's revenues (both national and subnational) again increased steeply. In 2005 the government collected approximately USD333 million in hydrocarbons' taxes, while this figure rose to almost USD790 million in 2006, and to USD2,241 million in 2014 (Figure 3.1).

The increase of public revenues not only depended on the changes in the hydrocarbons' regulation, which increased the tax rate from 18\% (Sánchez de Lozada) to $50 \%$ (Carlos Mesa) and 82\% (Evo Morales) of the production value. Another factor allowing the boom in the hydrocarbons sector was the increase in the international price of oil, which is closely linked to the price of natural gas. As the price of oil increased, so did the export price of natural gas.

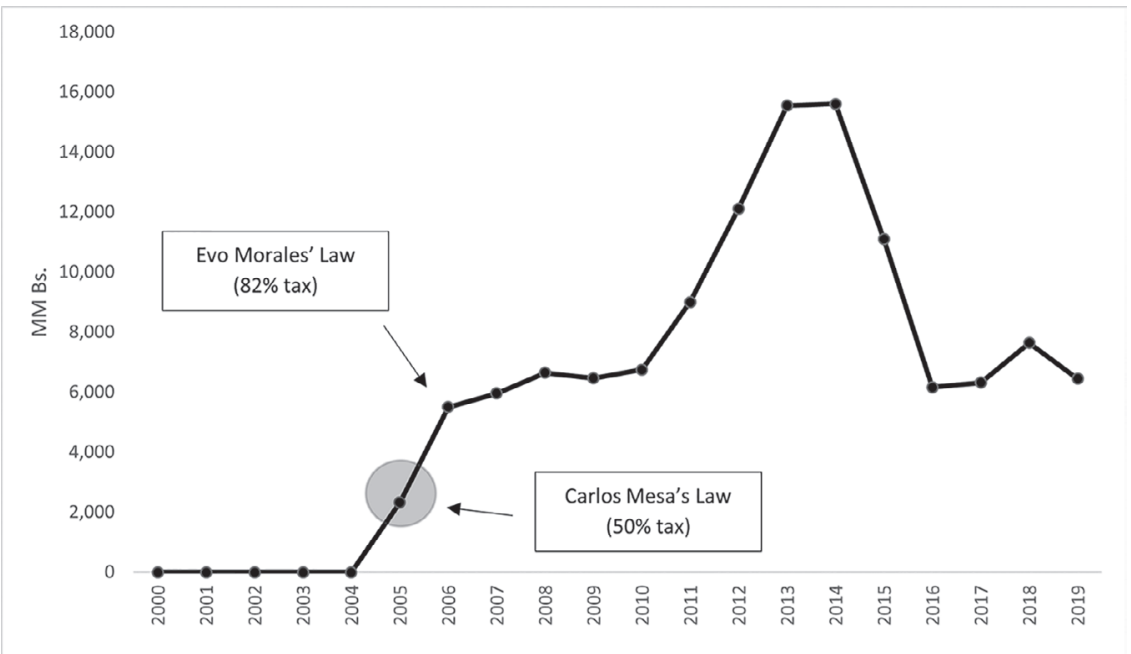

Figure 3.1 Hydrocarbons' taxes under different regimes (in millions of bolivianos)

Source: Own elaboration using data from Unidad de Análisis de Políticas Económicas y Sociales (UDAPE): www.udape.gob.bo/ 


\section{Pablo Evia Salas}

The boom in the hydrocarbons sector triggered a steady increase in government revenues, but also in expenditures. As Figure 3.3 depicts, government revenues and expenditures increased substantially from 2006 onwards. In the eight years from 2006 to 2013, the fiscal balance showed a surplus (as a matter

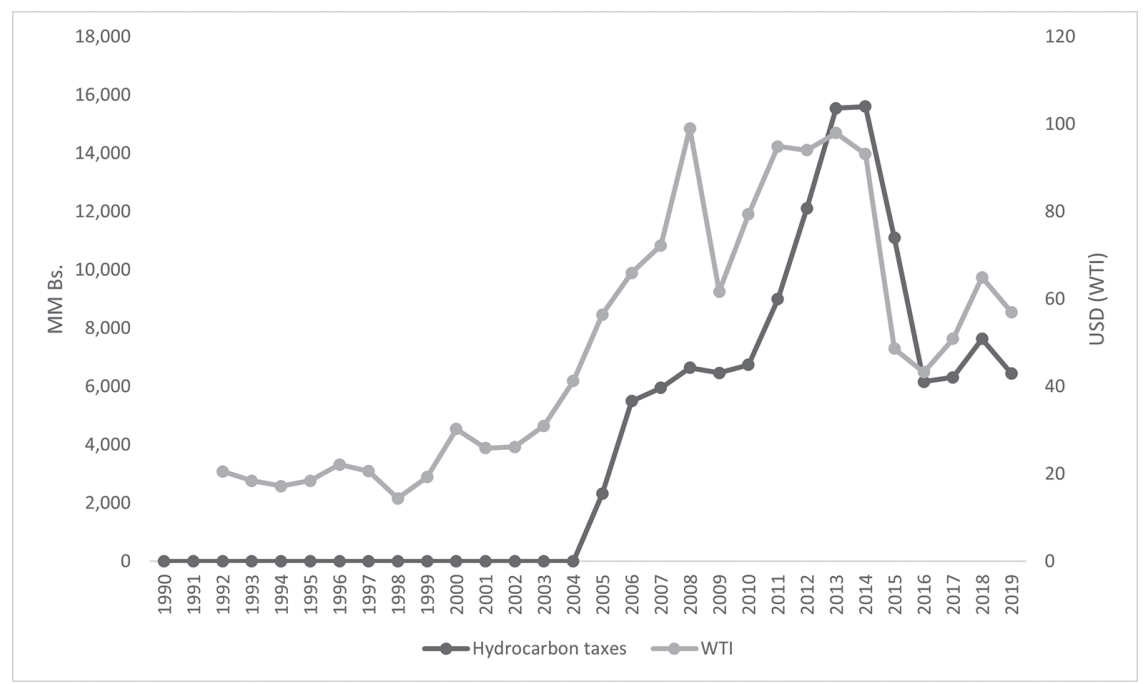

Figure 3.2 Hydrocarbons' tax and WTI

Source: Own elaboration using data from UDAPE

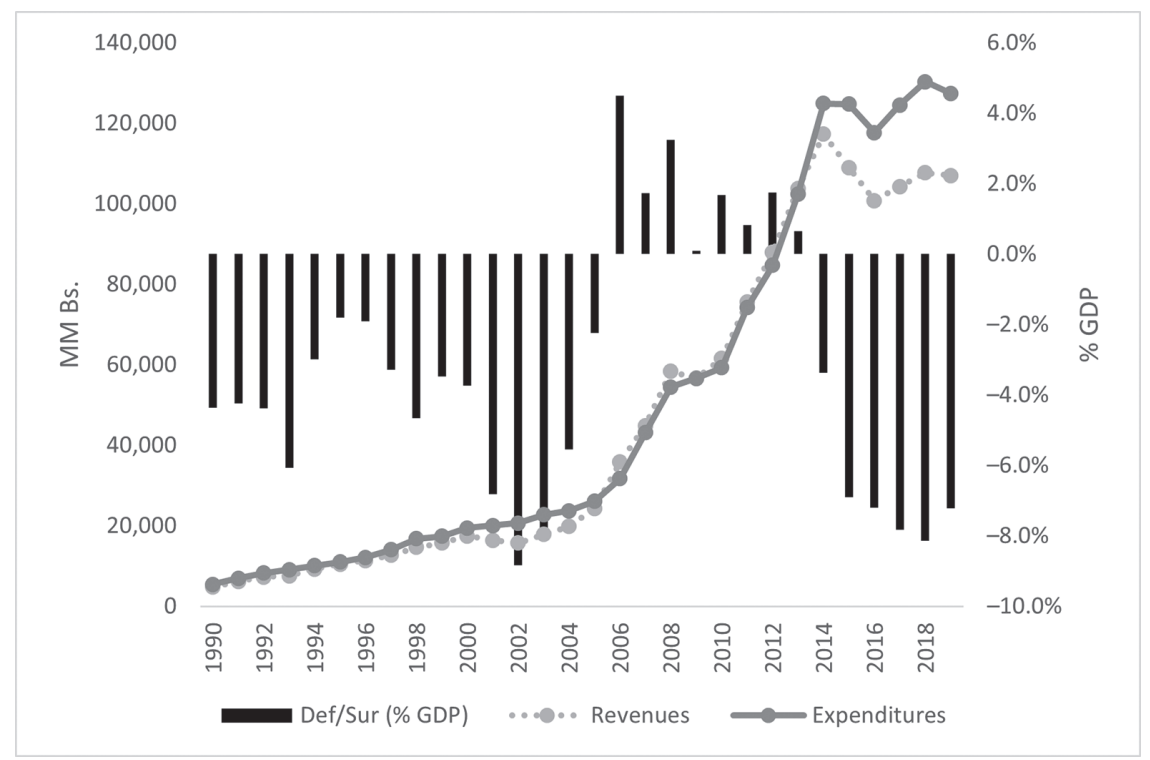

Figure 3.3 Fiscal balance, government expenditures and revenues

Source: Own elaboration using data from UDAPE 
of fact, the first surplus in 30 years). Some authors even drew parallels between it and the Marshall Plan of US aid to Western Europe. Morales (2014) calculated that during the booming period (2005-2013), the additional inflow of resources was around USD50 billion compared to USD130 billion under the Marshall Plan. However, the Bolivian fiscal balance benefited only temporarily during the phase of high oil prices. After 2013, and coinciding with the drop in the international oil price, the surplus turned into a deficit, reaching levels coincident with the crisis years (2002-2003).

\section{Bolivia's social protection floor}

With the extraordinary influx of revenues and following the example of other programs in the region (especially Oportunidades in Mexico and Bolsa EscolaBolsa Família in Brazil), the government of Evo Morales intended to establish a social protection system based in conditional cash transfers (CCTs) (Cechinni, 2019; Sojo, 2017).

CCTs consist of payments given to specific individuals provided that they fulfill certain conditions: for example, attending school or being subject to periodical medical check-ups. Those transfers intend to address poverty in the short term and break the intergenerational cycle of poverty by increasing the human capital of the recipients and their families (Ferreira \& Robalino, 2010, p. 22). Effective targeting is one of the features of CCTs that improve their effectiveness in reducing poverty.

In the Latin American region, the pioneering examples of Progresa-Oportunidades in Mexico and Bolsa Escola-Bolsa Família in Brazil during the 1990s inspired many other programs that rely upon conditional cash transfers. Ferreira and Robalino (2010) estimate that CCTs in Latin America benefit roughly 22 million households, range from 0.1 to 0.6 of GDP, and cover between $1.5 \%$ of the population (El Salvador) and $54 \%$ of the population (Bolivia). Thus, the social protection floor installed in Bolivia is one of the most extensive in the region and is considered key in the fight against poverty (Amarante \& Brun, 2018).

In current Bolivia, the most prominent cash transfers are BONOSOL/Renta Dignidad, a universal pension scheme given to the elderly; Bono Juancito Pinto (BJP), a conditional transfer given to children and youth in school-age; and Bono Juana Azurduy (BJA), another conditional cash transfer provided to expectant mothers and their newborns. The establishment of BJA and BJP aimed to increase the coverage of social protection recipients and, at the same time, to break the intergenerational cycle of poverty. The continuation of past programs, like BONOSOL/Renta Dignidad, contributed to reinforce this idea of providing integral support to the individual throughout their life cycle. Hence, the social policy system established in Bolivia resembles the Social Protection Floor (SPF) concept as promoted by the International Labor Organization (ILO, 2011). The ILO conceives SPF as an integrated set of social policies designed to guarantee income security and access to essential social services for all, paying particular attention to vulnerable groups and to protecting and empowering people across the life cycle (Harris, 2013, p. 113). In terms of its funding, SPF is essentially non-contributory and involves funding using public resources. 


\section{Unstable finances: a constraint for the future?}

There can be different sources to fund a social protection scheme. Generally, domestic resource mobilization is considered as the most efficient way of financing development (Harris, 2013, p. 117). Likewise, the literature warns against funding social protection with external sources because of their potential unsustainability. The notion of the project cycle unsustainability is frequent in those social protection schemes funded by external donors and implies that the horizon of planning of the institutions that provide support reaches up to four or five years. Usually, the donors or NGOs that finance social protection schemes in developing countries have a small window of commitment. The same idea applies to social protection schemes that are funded using volatile revenues, like taxes on commodities (Devereux, 2002, p. 31). The problem of financing social protection schemes (or social protection systems, as SPF) with natural resources taxation is that, in general, this funding is pro-cyclical and subject to the fluctuations of commodities' international prices (Loza, 2007). Moreover, if the transfers are funded using debt, this would reduce fiscal space in the future, limiting even more the use of the resources by the government (Harris, 2013, p. 127).

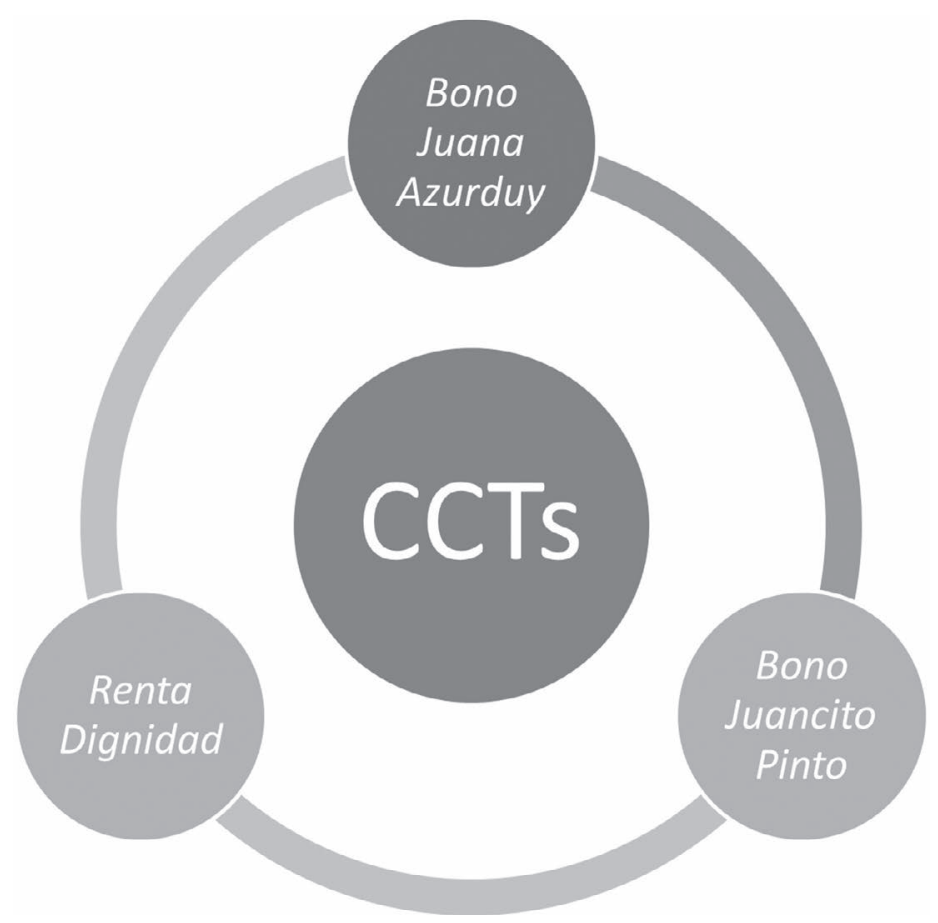

Figure 3.4 Bolivian CCTs and life cycle

Source: Own elaboration based on Millán et al. (2019) 
These dynamics can be observed in Bolivia and raise serious doubts regarding the financial sustainability of the domestic social protection floor enacted as a citizens' dividend of the resource boom. As explained before, reform of the hydrocarbons sector increased fiscal resources a great deal. These additional fiscal resources allowed the financing of existing social programs (Renta Digni$d a d$ ) and the creation of new ones (BJA, BJP) (Medinaceli \& Mokrani, 2010, p. 248). In this way, natural resources turned into the primary funding source for social purposes (Monterrey, 2013), linking expenditure on social protection with volatile international prices. When the economic boom ended, revenues decreased while expenditures remained high. As a consequence, in 2019, the fiscal deficit worsened to reach $8 \%$ of GDP, raising serious questions regarding the predictability of the social protection programs.

In the following, I illustrate this set of potential problems in detail for the three most important conditional cash transfer programs in Bolivia: Renta Dignidad, Bono Juana Azurduy, and Bono Juancito Pinto.

\section{BONOSOL/Renta Dignidad}

From its inception in the 1990s, the payment of BONOSOL was highly controversial due to the perception that the dividends of capitalized enterprises did not sufficiently back the resources needed for its payment (Müller, 2009). Indeed, the program faced problems of financial sustainability from the beginning. In its first payment in 1997, the BONOSOL amount of Bs1800 (roughly USD257) demanded a budget of USD90 million for paying the benefit to more than 360,000 recipients. However, the dividends of privatized enterprises only reached USD45 million. The remainder had to be covered by the Tesoro General de la Nación (TGN), the public budget in an amount of USD45 million (Gamboa, 2006).

Given this scenario, the payment of Bs1800 was largely unsustainable, and the amount was reduced to Bs455 (around USD65) from 1998 to 2001. In the year 2002, there was no payment of BONOSOL or Bolivida, while from 2003 to 2006 the amount and original name of BONOSOL were restituted.

Shortly after the new government of Morales had assumed in 2006, the BONOSOL scheme was changed to a monthly transfer of Bs350 (around USD50). The law that created Renta Dignidad (the "new" transfer) established the following points: the Renta Dignidad would reach all elderly more than 60 years old; those that had another pension benefit would only receive $75 \%$ percent of the benefit (USD37.50); and most importantly, the funding of the Renta Dignidad would be grounded in two sources: the dividends of the privatized enterprises, in the proportion that corresponds to the Bolivian stockholders and $30 \%$ of the newly established direct Hydrocarbon Tax (IDH-Impuesto Directo a los Hidrocarburos).

While the first two changes in the legislation implied a different design of the transfer, the most important modification came in the cash transfer funding. While BONOSOL payment was covered using the privatization profits, a link between social policy and the revenues from the exports of 
natural gas was created with the establishment of Renta Dignidad. Thus, as long as the government had high revenues due to favorable external circumstances (i.e., a boom in the commodities sector due to a hike in the international prices), the tax revenues designated to finance the transfer would be assured. However, in a highly volatile context, in which commodity prices are subject to demand and supply shocks, it would be, to say the least, a risky business to heavily rely upon hydrocarbons revenues to finance a cash transfer program.

And indeed, with the bust cycle sending international commodity prices plunging, the funding of the program became troublesome. Figure 3.5 shows the evolution of funding sources for Renta Dignidad. As can be seen, the component regarding the privatization revenues has evolved mirroring the hydrocarbons tax component: when the privatization revenues arise, there is less need to trust in the hydrocarbon tax component, and the converse is also true. In the last years, however, it can be seen that the component regarding the dividends of the privatized companies has evolved negatively, falling to a historical minimum, only comparable to the revenues in 2012.

Bolivia's funding of its Renta Dignidad provides an interesting example of the use of revenues from the exploitation of natural resources to fund social protection expenditures and highlights the potential pitfalls posed by the variability of such revenues. Buoyant oil prices allowed the program to be funded using only a part of the oil revenues. However, Bolivia's experience underscores that provisions also have to be made to secure funding when oil prices are less favorable and absorb

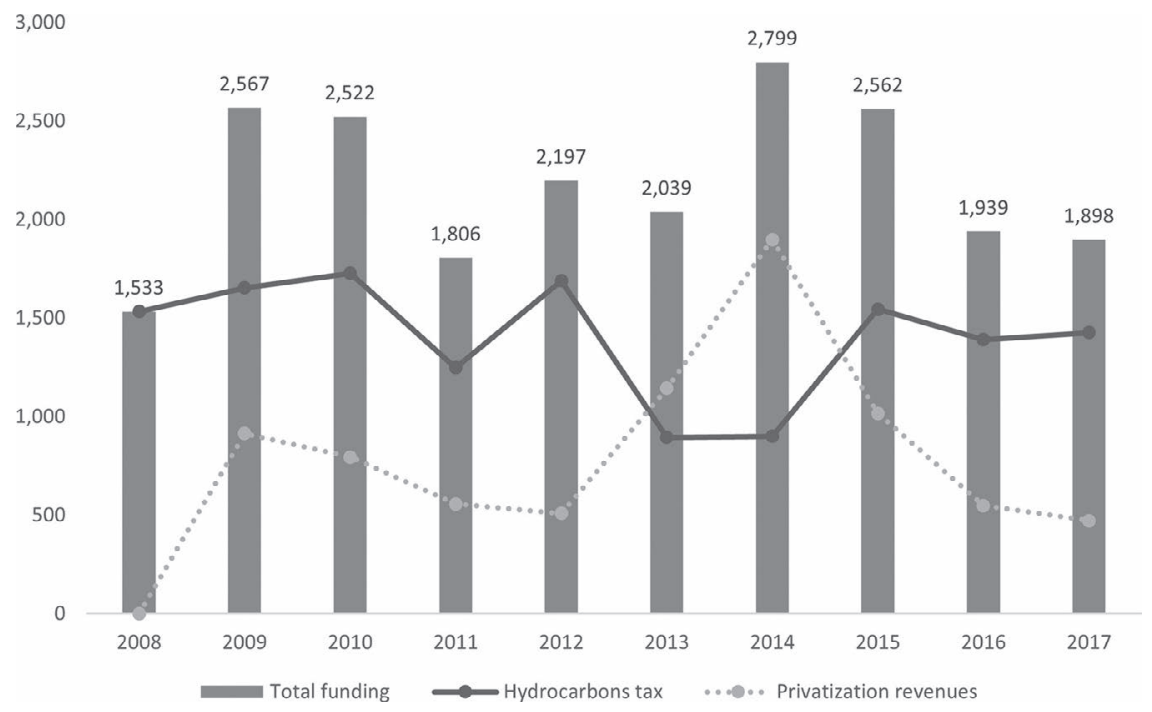

Figure 3.5 Renta Dignidad funding, hydrocarbons tax, and privatization revenues

Source: Own elaboration using data from UDAPE 
the impact of the inherent volatility of oil revenues, given that they are one of the most critical sources of funding for the government's overall expenditures (Harris, 2013, p. 133).

While the link between highly volatile oil prices and the revenues needed for the cash transfers to Bolivian pensioners has not had actual negative consequences for the payment of the transfer (e.g., a reduction in amount of benefit or in the number of recipients), there are some challenges regarding its sustainability over time. In the first place, there is a general concern with respect to the reduction in public resources due to the drop in oil prices observed in the last five years (Sánchez \& Velásquez, 2020). Several experts have expressed their belief that the resources collected by the national treasury will not be able to cover the total expenditure needed for Renta Dignidad, not to mention retirement income in general (Rodríguez Cáceres, 2021). The second concern is the high volatility of the source of funding for Renta Dignidad. While the bonanza from the middle 2000s to 2010s has allowed the government to sustain and even increase the amount of the Renta Dignidad over time, unstable oil prices will make it harder to adopt a similar pattern in the following years.

\section{Bono Juancito Pinto}

The Bono Juancito Pinto was established in 2006, and it consists of the payment of Bs200 (USD28) annually to school students (both primary and secondary school) that are enrolled in public schools. The payment is conditional on an attendance rate of more than $80 \%$ of the school days during the previous school year (running from February to November).

While the funding mechanism is not specific regarding the funding source for the transfer payment, de facto it was financed by the revenues generated by the "nationalized" hydrocarbons enterprise, YPFB. Thus, also this transfer is inherently linked to the volatile hydrocarbons revenues.

As in the case with Renta Dignidad, in the first years of the transfer the resources provided by YPFB were enough to cope with the financial obligations of the program. However, with the revenues shrinking and the overall budget expanding (in 2006, the budget was USD248.5 million; in 2019, the budget was USD461 million), additional funding sources had to be found considerably increasing the number of revenues' sources comparing it to its first payment in 2006. In 2019, besides YPFB, these include a variety of public sources ranging from food firms to commercial banks to the cable car transport enterprise in La Paz, amongst others (see Table 3.1).

While the fact that the government was able to ensure more funding sources for the 2019 budget could be qualified as a "success", several concerns arise from the evolution of the funding structure from 2006 to 2019. The first one is associated with a problem of incentives. During the Morales administration, several state-owned enterprises were created, on the grounds that the state should be strategically positioned as a major producer. Most of these newly 
Table 3.1 Source of funding for Bono Juancito Pinto (2019)

\begin{tabular}{ll}
\hline Source of funding & Business \\
\hline YPFB & Oil company \\
COMIBOL & Mining company \\
BOA & Airline \\
DAB & Customs \\
ENTEL & Telecommunications company \\
COFADENA & Military company \\
ENDE & Electricity company \\
TAB & Air cargo company \\
VINTO & Mining company \\
EBA & Food processing company \\
Nueva EBA & Food processing company \\
SABSA & Airport administration company \\
MI TELEFÉRICO & Cable car company \\
TAM & Airline (military) \\
ABE & Aeronautics and Space agency \\
ASPB & Port management \\
BTV & TV company \\
LACTEOSBOL & Food processing company (milk) \\
EBC & Building company \\
BANCO UNIÓN & Bank \\
EMAPA & Food processing company \\
\hline
\end{tabular}

Source: Own elaboration using data from UDAPE

created enterprises ended up providing resources for the funding of Bono Juancito Pinto (among other diverse tasks). There is a general concern with the diverse burdens that these companies need to cover, given the different goals that governments assign to them, ranging from jobs creation to funding social policy (Lin et al., 1998; Shirley \& Walsh, 2000). This diversity of functions and the multiplicity of objectives for the public enterprises could be problematic from the point of view of the sustainability of the financial resources required by the social transfer.

Another source of concern related to the numerous sources of funding for the Bono Juancito Pinto is more general, related to the creation of fiscal space to gather the resources needed to cover the obligations acquired by the state. While creating enough funding (i.e., the size) is actually very important to sustain the transfer over time, a focus on quality of these resources should also be taken into account (an element of quality being how sustainable are the resources). 


\section{Bono Juana Azurduy}

The Bono Juana Azurduy (BJA) is a conditional cash transfer program introduced in 2009. The transfer beneficiaries are pregnant women and children up to two years old, conditional on the regular attendance to medical check-ups. The program's cash payments can sum up to Bs1820 (USD260) per mother/child if all the check-ups are correctly undertaken. In addition to these cash payments, the program also covers births in public hospitals.

As in the case of BJP, the source of funding for the BJA transfer was neither clearly stated from the beginning. The supreme decree establishing the transfer affirms that "according to availability, the 'Juana Azurduy" transfer will be financed with resources from a) The National Treasury; b) Donations and external/internal credits; c) Transfers from public and private entities and institutions" (Supreme Decree 066-Creation of Bono Juana $A z u r d u y)$.

In 2012, Law 211 mandated that the BJA would be financed from then on with the central bank's foreign reserves yields. Apart from the public budget, foreign reserves (FX reserves) were the other winner of the commodities' windfall, given its close relationship with exports. The export revenues are paid in dollars (or any other foreign currency), yielding an increase in FX reserves. Figure 3.6 shows the relationship between FX reserves and the international

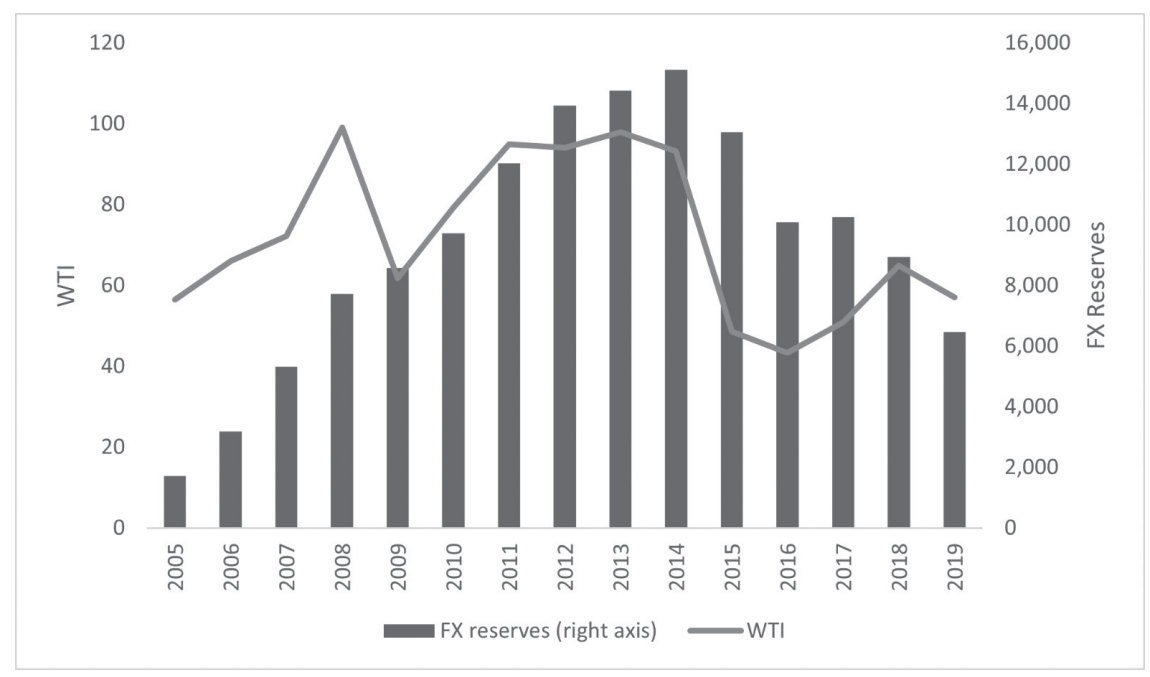

Figure 3.6 Relationship between FX reserves and WTI

Source: Own elaboration using data from UDAPE 
price of oil. We see that the relationship is positive, implying once again that the funding source of the BJA transfer is closely linked to the variations in the international prices of commodities.

Again, the high dependence on foreign revenues constitutes a potential fragility, since a change in the conditions of gas exports would put the continuity of social protection policies at risk (Monterrey, 2013). In addition, financing for social policy is not normally a core competence of a central bank, and this additional burden could in fact distort the customary objective of maintaining price level stability in the economy. As in the case of the funding of the Bono Juancito Pinto, although there have been no serious consequences so far (in the sense of suspension of payments, etc.), there is a clear problem of incentives between a central bank's traditional objectives (i.e., maintaining currency's purchasing power, financial stability, or other related) and providing funding for social policy instruments. The political and economic independence of central banks is generally understood as a desirable feature of modern monetary and financial policy (Alesina \& Summers, 1993) and a guarantee for macroeconomic stability (Grilli et al., 1991). In this sense, relying on the central bank's foreign exchange reserves for funding a social transfer program could distort the objectives of maintaining the currency power purchasing and pursuing financial stability.

\section{Conclusion}

This chapter has explored the interaction between social policy innovations, understood as a type of institutional change, and the resource boom in Bolivia during the years 2003-2014. It has been shown that this boom is related to key reforms in the natural resource sector which were introduced in Bolivia since the 1990s. These reforms paved the way for gathering more resources from the natural resource sector (mainly natural gas), which allowed the successive governments to build a social protection system reflecting the increased government fiscal revenues. This system could be conceived of as a social protection floor that acts as a citizen's dividend of the resource boom.

The importance of these social protection innovations in overcoming the high poverty and inequality rates present in the country is undeniable. Nevertheless, by linking the different cash transfers to the volatile global prices of oil and gas, an element of instability is introduced in the system. This element may potentially reduce the effects of the social protection system in the future, by limiting its capacity to provide support to those in need. As in the case of BONOSOL in the past, the instability in the sources of funding could lead in the worst scenario to a suspension in the payments of the social transfers with negative consequences for all the recipients. In the case of the Bono Juancito Pinto, such instability has already been observed. The downturn in the oil industry, with declining global prices in the sector, have pushed the government to be "creative" at the time of looking for sources of finance for the protection 
floor, skimming resources from a wide array of public companies. While some of these already confront problems of financial sustainability, converting them into sponsors of the national social programs may be a liability for their futures.

As mentioned before, the literature convincingly argues that using domestic sources for financing social protection systems is critical for their success, as is the existence of an efficient tax administration (Hujo et al., 2010). Elements of both reforms include avoiding rent-seeking behavior, as well as fiscal evasion and avoidance, which are phenomena that tend to appear especially in resource economies. Besides, applying effective taxes to income and real property would enhance the government's fiscal position. (Harris, 2013, p. 120).

In the case of Bolivia, this alternative would imply the adoption of a progressive tax reform enabling the state to raise money from its citizens to protect its citizens. For several reasons, such a comprehensive reform of the national tax system has not been on the political agenda so far. Particularly, the high degree of economic informality prevents raising revenues coming from a progressive tax (like, for example, an income tax). Also, increasing taxes is a sensible subject in Bolivia that elicits resistance from wealthy and poor sectors alike. In this sense, the use of the revenues stemming from the natural resource sector to build a social protection floor was a way to satisfy both the demands of elites as well as the necessities of the poor. However, given the instabilities arising from its design, the local mobilization of resources by means of a progressive tax reform will be an urgent task ahead.

\section{Note}

1 Chaco heroes, in reference to the war against Paraguay over control of the northern part of the Gran Chaco region (known in Spanish as Chaco Boreal) of South America, which was thought to be rich in oil.

\section{References}

Alesina, A., \& Summers, L. H. (1993). Central bank independence and macroeconomic performance: Some comparative evidence. Journal of Money, Credit and Banking, 25(2), 151-162. https://doi.org/10.2307/2077833

Amarante, V., \& Brun, M. (2018). Cash transfers in Latin America: Effects on poverty and redistribution. Economía, 19(1), 1-31. www.jstor.org/stable/90025861

Antelo, E. (2000). Políticas de estabilización y de reformas estructurales en Bolivia a partir de 1985. In L. C. Jemio \& E. Antelo (Eds.), Quince años de reformas estructurales en Bolivia: Sus impactos sobre inversión, crecimiento y equidad (pp. 15-98). Universidad Católica Boliviana San Pablo, IISEC.

Arezki, R., Dupuy, A., \& Gelb, A. (2012). Spend or send. Finance and Development, 49(4), 28-31. https://doi.org/10.5089/9781475576122.022.A011

Banco Central de Bolivia. (2019). Boletín del sector externo (No. 85). BCB.

Cechinni, S. (2019). Protección social universal en América Latina y el Caribe: Textos seleccionados 2006-2019. CEPAL. https://repositorio.cepal.org/handle/11362/44995 
Devereux, S. (2002). Social protection for the poor: Lessons learnt from recent international experience. IDS Working Paper No. 142. Sussex: Institute of Development Studies. http:// opendocs.ids.ac.uk/opendocs/bitstream/handle/20.500.12413/3907/Wp142.pdf

Ferreira, F. H. G., \& Robalino, D. (2010). Social protection in Latin America: Achievements and limitations. Policy Research Working Papers 5305. World Bank.

Gamboa, R. (2006). Evaluación de la sostenibilidad del pago del Bonosol. Revista de Análisis Económico, 21, 62-82. www.udape.gob.bo/portales_html/analisisEconomico/analisis/ vol21/Gamboa21.pdf

Grilli, V., Masciandaro, D., Tabellini, G., Malinvaud, E., \& Pagano, M. (1991). Political and monetary institutions and public financial policies in the industrial countries. Economic Policy, 6(13), 341-392.

Harris, E. (2013). Financing social protection floors: Considerations of fiscal space. International Social Security Review, 66(3-4), 111-143. https://doi.org/10.1111/issr.12021

Hujo, K., Gaia, E., \& McClanahan, S. (2010). Chapter 8: Financing social policy. In Combating poverty and inequality: Structural change, social policy and politics (pp. 207-228). UNRISD.

Instituto Nacionalde Estadística-INE. (2020). Boletínsectorial dehidrocarburos $N^{\circ} 1$. INE. www. ine.gob.bo/index.php/publicaciones/boletin-sectorial-hidrocarburos-no1-2020/

International Labour Organization-ILO. (2011). Social protection floor for a fair and inclusive globalization: Report of the Advisory Group chaired by Michelle Bachelet. ILO. www. ilo.org/wcmsp5/groups/public/-dgreports/-dcomm/-publ/documents/publication/ wcms_165750.pdf

Lin, J. Y., Cai, F., \& Li, Z. (1998). Competition, policy burdens, and state-owned enterprise reform. The American Economic Review, 88(2), 422-427. www.jstor.org/stable/116960

Loza, G. (2007). Diseño de la red integral de protección social en Bolivia. Revista de Análisis Económico, 22, 164-196. www.udape.gob.bo/portales_html/analisisEconomico/analisis/ vol22/7DRIPS.pdf

Medinaceli, M., \& Mokrani, L. (2010). Impacto de los bonos financiados con la renta petrolera. Umbrales. Revista del postgrado multidisciplinario en Ciencias del Desarrollo, 20, 223-263.

Millán, T. M., Barham, T., Macours, K., Maluccio, J. A., \& Stampini, M. (2019). Long-term impacts of conditional cash transfers: Review of the evidence. The World Bank Research Observer, 34(1), 119-159. https://doi.org/10.1093/wbro/lky005

Monterrey, J. (2013). Sistemas de protección social en América Latina y el Caribe: Estado Plurinacional de Bolivia. Documentos de Proyectos No. 553. CEPAL. http://hdl.handle. net/11362/4103

Morales, J. A. (2014). Los ingresos extraordinarios de Bolivia en el periodo 2006-2013: Una visión de conjunto. In J. A. Morales (Ed.), ¿Dónde está la plata? Los ingresos extraordinarios de la bonanza 2003-2013 (pp. 9-30). Fundación Milenio.

Müller, K. (2009). Contested universalism: FromBonosolto RentaDignidadinBolivia. International Journal of Social Welfare, 18(2), 163-172. https://doi.org/10.1111/j.1468-2397.2008.00579.x

Robles, M., Rubio, M. G., \& Stampini, M. (2019). Have cash transfers succeeded in reaching the poor in Latin America and the Caribbean? Development Policy Review, 37(2), 85-139. https://doi.org/10.1111/dpr.12365

Rodríguez Cáceres, G. (2021). ¿Prohibido envejecer en Bolivia? Desafíos del sistema integral de pensiones. In L. M. Calvo, A. Baudoin, F. Wanderley, W. Gómez, \& J. Badani (Eds.), Bolivia debate: Un futuro sustentable (pp. 18-24). UCB et al. www.ucb.edu.bo/wp-content/ uploads/2021/02/Separata_Bolivia_Debate_compressed_1.pdf\#page $=18$

Romero, F. (1988). Fondo social de emergencia, Bolivia. CEPAL. hdl.handle.net/11362/33246 
Sánchez, S., \& Velásquez, R. (2020). Situación de la renta petrolera en Bolivia. Serie de debate público, 82. Fundación Jubileo. https://jubileobolivia.org.bo/Publicaciones/ Revistas-Especializadas/Situacion-de-la-Renta-Petrolera-en-Bolivia

Shirley, M. M., \& Walsh, P. (2000). Public vs. private ownership: The current state of the debate. Policy Research Working Papers. World Bank. https://doi.org/10.1596/1813-9450-2420

Sojo, A. (2017). Protección social en América Latina: La desigualdad en el banquillo. Libros de la CEPAL, N 143 CEPAL. 